\title{
THE DISTRIBUTION AND HABITAT REQUIREMENTS OF THE GENUS OROBANCHE L. (OROBANCHACEAE) IN SE POLAND
}

\author{
RENATA PiwowarCZYK ${ }^{1}$, Piotr CHMIELEWSKI ${ }^{2}$, ANNA CWENER ${ }^{3}$ \\ ${ }^{1}$ Department of Botany, Institute of Biology, Jan Kochanowski University \\ Świętokrzyska 15, 25-406 Kielce, Poland \\ e-mail: renka76@wp.pl \\ ${ }^{2}$ Zamość Nature Society \\ Partyzantów 74/59, 22-400 Zamość, Poland \\ ${ }^{3}$ Department of Geobotany, Institute of Biology, \\ Maria Curie-Skłodowska University \\ Akademicka 19, 20-033 Lublin, Poland
}

(Received: March 11, 2010. Accepted: October 10, 2010)

\begin{abstract}
The distribution of the genus Orobanche in SE Poland is presented. The study area stretches between the Vistula and the Bug rivers, and comprises the Polish areas of the Lublin-Lwów Upland, the Wołyn Upland and the southern part of Polesie. Eight species of the genus Orobanche: O. alba, O. alsatica, O. arenaria, $O$. caryophyllacea, $O$. elatior, O. lutea, O. pallidiflora, O. picridis, were collected during floristic investigations conducted between 1999 and 2010. The hosts, abundance and habitat preferences at the localities are given and a supplemented map of the distribution in SE Poland is included.
\end{abstract}

KEY WORDS: Orobanche, distribution, habitat preferences, host, Lublin-Lwów Upland, Wołyń-Podole Upland, SE Poland.

\section{INTRODUCTION}

The genus Orobanche L. belonging to the family Orobanchaceae contains species lacking chlorophyll that are holoparasites of other vascular plants. It is one of the most critical genera of the flora in Poland and worldwide, and is notoriously difficult to determine, especially when dry. Orobanche species occur mostly in warmer regions of the temperate zone, in particular in the Mediterranean basin. Polish localities are at the northern limit of its range. Approximately 200 Orobanche species have been reported worldwide (Pusch and Günther 2009) and ca. 45 taxa are known from Europe (Chater and Webb 1972). Seventeen species of the genus Orobanche are known to occur in Poland, including two species considered to be ephemerophytes (Mądalski 1967; Zając and Zając 2001; Halamski 2005; Piwowarczyk 2010a, 2011). Localities of many species of the genus Orobanche have not been confirmed for many years. A number of taxa were incorrectly identified, which caused confusion in the dates of their occurrence. Orobanche species are rare and threatened with extinction both in Poland and in Europe. As many as eleven species are included in the red list of the vascular plants in Poland (Zarzycki and Szeląg 2006) and two in the
Polish red data book of plants (Zarzycki and Kaźmierczakowa 2001).

In Poland, the taxa are mostly concentrated in the range of xerothermic habitats in the belt of Polish uplands: ŚląskKraków Upland, Małopolska Upland, south-eastern uplands, as well as in the lower Oder valley and the Vistula valley (Zając and Zając 2001).

A number of new or verified localities of eight species belonging to the genus Orobanche, including species endangered in Poland, not confirmed for many years or new to the study area, were recorded during floristic investigations conducted in the south-eastern uplands between 1999 and 2010. The data on occurrence of the species in the area are scarce and scattered. They are often found in the older literature. Descriptions of the localities are often general or fragmentary (e.g. Paczoski 1888; Mądalski 1967; Fijałkowski 1994, 1995; Urban and Luczycka-Popiel 1995; Kucharczyk 2001).

\section{THE STUDY AREA}

The study area stretches between the Vistula and the Bug rivers. It comprises the Polish areas of the Lublin-Lwów 
Upland, Wołyń Upland and the southern part of Polesie. Natural conditions observed in the area are mostly influenced by the geological structure and the climate. The geological structure is formed by rocks of the Cretaceous period with a loess cover deposit. Landforms are diversified and include monadnocks, hills, continental plateaux, closed drainage depressions and valleys, as well as ravined valleys, developed as a result of different resistance levels to erosion of chalky rocks. On the other hand, a dense network of ravines has formed in sites covered with a thicker layer of loesses. The climate is temperate continental: the mean annual precipitation sum is ca. $550 \mathrm{~mm}$ and the mean annual temperatures are $7^{\circ} \mathrm{C}$. The highest values of maximum air temperature exceed $35^{\circ} \mathrm{C}$, the lowest values of minimum air temperatures fall below $-30^{\circ} \mathrm{C}$. Occurrence of days with frost is limited to period from November to March, sporadically the frosty days are noted in April or October. Length of vegetative period ranges from 211 to 220 days. A relatively high insolation is recorded in the Lublin and the Wołyń uplands (Kaszewski 2008). These conditions are favourable for the occurrence of xerothermic vegetation. Thermophilous species grow on baulks, roadsides and in fallow fields while more typical grasslands develop on steep slopes of river valleys and on chalky outcrops. Grasslands representing Thalictro-Salvietum pratensis or less frequently Koelerio-Festucetum rupicolae, Sisimbrio-Stipetum capillatae, Adonido-Brachypodietum pinnati or Origano-Brachypodietum associations (Festucetalia valesiacae order, Festuco-Brometea class) develop on the loess substrate. Inuletum ensifoliae and its degenerated and succession forms usually occur on calcareous substrate (Fijałkowski 1991).

\section{MATERIAL AND METHODS}

The occurrence of species belonging to the genus Orobanche in south-eastern Poland in the Polish and Ukrainian uplands province, the Lublin-Lwów and Wołyń-Podole uplands subprovince (Kondracki 2001) is discussed. Investigations were conducted in the following macroregions: Lublin Upland (mesoregions: Middle Vistula Gap, Grabowiec Interfluves, Zamość Depression, Świdnik Plateau, Giełczew Elevation, Urzędów Heights); Roztocze (Middle Roztocze); Polesie Wołyńskie (Chełm Hills, Dubienka Depression); Wołyń Upland and Małe Polesie (Hrubieszów Basin, Sokal Ridge, Bełz Plain).

Data were collected between 1999 and 2010. Studies were intensified from 2006 to 2009. The list of localities,

\footnotetext{
Abbreviations:

DG - Działy Grabowieckie (Grabowiec Interfluves); GS - Grzęa Sokalska (Sokal Ridge); KH - Kotlina Hrubieszowska (Hrubieszów Basin); MPW - Małopolski Przełom Wisły (Middle Vistula Gap); OB Obniżenie Dubieńskie (Dubienka Depression); PC - Pagóry Chełmskie (Chełm Hills); PI - Przedgórze Iłżeckie (Iłża Foreland); PŚ - Płaskowyż Świdnicki (Świdnik Plateau); PZ - Padół Zamojski (Zamość Depression); RB - Równina Bełska (Bełz Plain); RŚ - Roztocze Środkowe (Middle Roztocze); WG - Wyniosłość Giełczewska (Giełczew Elevation); WS Wyżyna Sandomierska (Sandomierz Upland); WU - Wzniesienia Urzędowskie (Urzędów Heights).

The herbarium material was deposited in the Herbarium of the Jan Kochanowski University in Kielce (KTC), and in the Herbarium of the Maria Curie-Skłodowska University in Lublin (LBL).
}

including a full list of published localities and revised herbarium material data, will be published in a monographic study of the genus Orobanche in Poland (Piwowarczyk M.Sc.).

The species are arranged alphabetically. Their nomenclature follows Mirek et al. (2002) and syntaxa are distinguished after Matuszkiewicz (2006). The list of species is arranged alphabetically by the abbreviate Polish name of a mesoregion. The location in the ATPOL grid is provided for each locality according to Zając (1978). Digits that follow letter symbols of the large square are as follows: the two first digits - the number of the $10 \mathrm{~km}$ square, two further digits - the number of the $1 \mathrm{~km}$ square. The description of each locality contains: the mesoregion (list is given below), location, habitat description, population abundance; the ATPOL grid unit, geographical co-ordinates (using a GPS receiver), revised exsiccatae (the collection date and the collector's name) and the herbarium acronym are given for most localities. Habitats are given for all species and plant associations in which a species was observed are provided for the majority of species. The distribution mapped in $1 \mathrm{~km}$ cartogram units according to the ATPOL guidelines (Zając 1978) based on the localities specified on the list is given for each taxon. Host plants were observed at localities of individual species by delicately exposing the soil.

\section{RESULTS \\ LIST OF SPECIES AND LOCALITIES}

\section{Orobanche alba Stephan ex Willd.}

$O$. alba prefers insolated S- and SW-facing grasslands, less frequently scrub communities with Juniperus communis on shallow chalky rendzinas. It is mostly recorded in plant associations difficult to classify that form a mosaic of species belonging to the Cirsio-Brachypodion pinnati alliance and the Trifolio-Geranietea sanguinei class. It flowers from mid June to mid July. Salvia verticillata is the host of $O$. alba in the study area (Fig. 1).

List of localities: DG: 1. Dworzyska - the steep SWfacing slope of the Wieprz valley, Thalictro-Salvietum pratensis grassland developing on loess substrate $(>10)$, GE6211, 5055'45”N, 2309'53”'E, leg. A. Cwener \& M. Wrzesień, 17.07.2006 (LBL), leg. A. Cwener, 24.06.2007 (LBL); 2. Żmudź - by the SW border of the complex of forested xerothermic grasslands neighbouring on the “Żmudź” reserve (<5), GE5507, 51 ${ }^{\circ} 00^{\prime} 16^{\prime} \mathrm{N}, 23^{\circ} 40^{\prime} 01$ ”'E, vid. P. Chmielewski, 2007; 3. Wólka Leszczańska - two populations: the first is situated in a narrow belt of calcareous xerothermic grassland belonging to the CirsioBrachypodion pinnati alliance between the "Żmudź" reserve and the Wólka Leszczańska village $(>20)$, the second is located in a midfield patch of juniper scrub with fringe vegetation of the Trifolio-Geranietea sanguinei class between Wólka Leszczańska and Kolonia Maziarnia villages (>5), GE4596, GE5506, GE5515, 51 ${ }^{\circ} 00^{\prime} 36^{\prime} \mathrm{N}$,

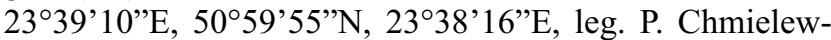
ski, 2007, leg. R. Piwowarczyk, 08.06.2007 (KTC); 4. Kolonia Leszczany - thermophilous juniper scrub and fringe communities in the vicinity of the forest complex overgrowing the western slope of a calcareous hill known as Kurawica (>40), GE5512, 51 ${ }^{\circ} 00^{\prime} 19^{\prime \prime} \mathrm{N}, 23^{\circ} 35^{\prime} 41^{\prime \prime} \mathrm{E}$, 
vid. A. Cwener, P. Chmielewski \& R. Piwowarczyk, 2007, leg. P. Chmielewski \& R. Piwowarczyk, 2007 (KTC). 5. Leszczany - a fallow field near a former limestone excavation pit by the Żmudź - Kumów Majoracki road $(<5)$. The species disappeared after the fallow field had

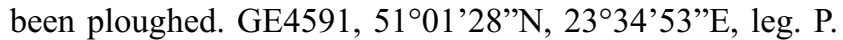
Chmielewski \& R. Piwowarczyk, 15.07.2006 (KTC); 6. Kumów Majoracki - loose juniper scrub and fringe communities on the western calcareous slope of a small water course flowing into the Krzywólka river, on the edge of the "Płachsiocha" forest complex (>10), GE4499, 51 ${ }^{\circ} 01$ '18"N, 2333'03”E, vid. P. Chmielewski, 01.07.2007. 7. Huszczka Duża - grasslands of the Inuletum ensifoliae association situated on a vast calcareous slope with glades with xerothermic vegetation (>50), GE6393, GE7303, 5050'40'N, $23^{\circ} 18^{\prime} 54^{\prime \prime}$, vid. A. Cwener, 2006 (LBL); 8. Białowody a xerothermic grassland of the Cirsio-Brachypodion pinnati alliance on a calcareous slope, ca. $400 \mathrm{~m} \mathrm{E}$ of a dirt road from Grabowiec to Uchanie (>30), GE6554, 5052’34”N, 2336'51'”E, vid. P. Chmielewski, 27.06.2008; 9. Skomorochy Małe - a xerothermic grassland of the CirsioBrachypodion pinnati alliance, on the calcareous slope of the Wolica valley, ca. $400 \mathrm{~m} \mathrm{E}$ of the village buildings

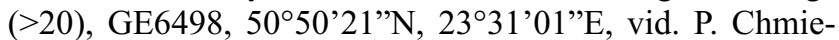
lewski, 01.07.2007; 10. Grabowiec-Góra - a xerothermic grassland forested with ashes and larches on the "Wzgórze Zamkowe" hill, by the gravel road from Grabowiec to Bronisławka (<10), GE7521, 5049'01'”N, 2333'37’E, vid. P. Chmielewski, 01.07.2007; GS: 11. Komarów-Wieś - a xerothermic grassland on the calcareous slope of a dry small valley joining the Sieniocha river valley, ca. $200 \mathrm{~m} \mathrm{E}$ of the buildings in the Brzęczyna settlement $(>30)$, GE9445, 50³7'03'N, 2327'26’E, vid. P. Chmielewski, 2007 ; 12. Kraczew - a calcareous slope, ca. $200 \mathrm{~m}$ E of the village buildings (>20), GE9563, 50³5'51'N, 2334'05'E, vid. W. Michalczuk, 2007, leg. R. Piwowarczyk, 2007 (KTC); KH: 13. Gródek (Czumów) - xero-

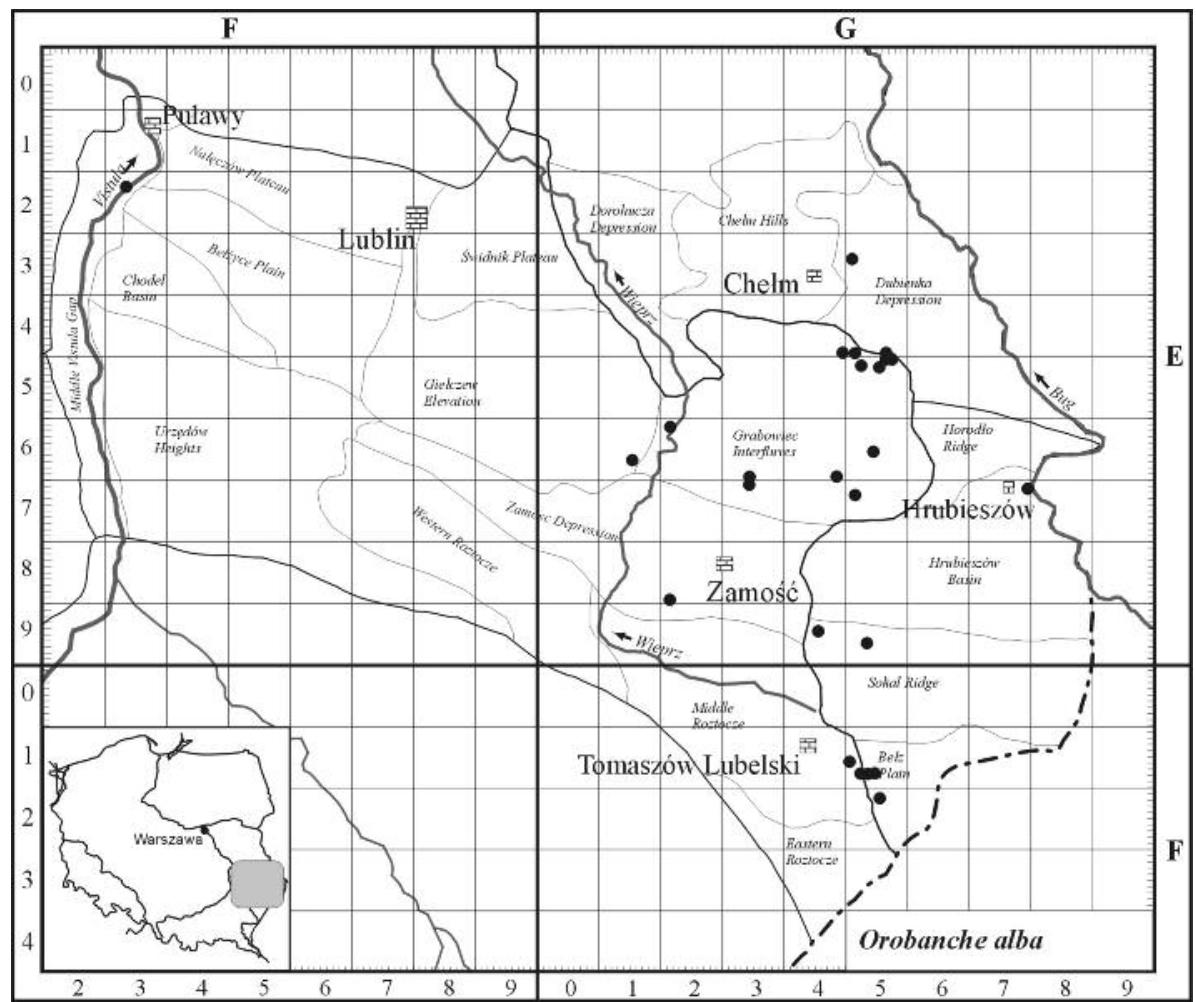

Fig. 1. Distribution of Orobanche alba in SE Poland. thermic grasslands on high midfield baulks (western slopes of an old earthwork in Gródek) (>15), GE7719, 5047'46”N, 2357'11'”, leg. A. Cwener, 28.08.2007 (LBL); MPW: 14. Męćmierz - xerothermic grasslands and fallow fields situated on a calcareous hill, ca. $300 \mathrm{~m} \mathrm{SW}$ of village buildings $(<50)$, FE2322, $51^{\circ} 18^{\prime} 25^{\prime}$ 'N , 21 ${ }^{\circ} 54^{\prime} 28^{\prime \prime} \mathrm{E}$, leg. P. Chmielewski \& R. Piwowarczyk, 23.08.2008 (KTC); PC: 15. Brzeźno near Chełm - calcareous elevations surrounded by meadows, of the village in the "Brzeźno" peat bog reserve $(>50)$, GE3540, $51^{\circ} 09^{\prime} 18^{\prime} \mathrm{N}$, $23^{\circ} 35^{\prime} 31^{\prime \prime E}$, leg. J. Wójciak \& R. Piwowarczyk, 12.07. 2008 (KTC); PZ: 16. Kąty II - xerothermic grasslands situated on a midfield hill known as Wieprzecka Góra (>20), GE8291, 5040’37'N, 2307'31”E, leg. R. Piwowarczyk, W. Michalczuk \& P. Chmielewski, 13.07. 2008 (KTC); RB: 17. Kolonia Jarczów II - xerothermic grasslands and fringe communities situated in the southern part of two forest complexes located ca $1 \mathrm{~km} \mathrm{~S}$ of the village buildings ( $>20$ ), GF1573, GF1574, 50²4'14"N, 2334'24'E; 50²4'10”N, 2333'06”'E, vid. P. Chmielewski \& R. Piwowarczyk, 13.07.2006; 18. Machnów Stary xerothermic grasslands in the "Machnowska Góra" reserve (>50), GF2515, 50²2’10”N, 2335’20”E, leg. P. Chmielewski \& R. Piwowarczyk, 09.06.2007 (KTC); 19. Korhynie - xerothermic grasslands with juniper and fringe communities in the "Korhynie" ecological site, ca. $300 \mathrm{~m}$ E of the village buildings $(<10)$, GF1572, 50²4'19'N, 2332'31'E, vid. A. Cwener \& P. Chmielewski, 28.07. 2009; RŚ: 20. Przeorsk - a xerothermic grassland on the slopes of a hill known as Łysa Góra $(>30)$, GF1550, $50^{\circ} 25^{\prime} 22^{\prime} \mathrm{N}, 23^{\circ} 31^{\prime} 01^{\prime} \mathrm{E}$, leg. P. Chmielewski \& R. Piwowarczyk, 09.06.2007 (KTC); WG: 21. Bryczówki fringe communities on the slope of a calcareous ravine, ca. $100 \mathrm{~m}$ from the village buildings (5), GE6165, 50 $52^{\prime} 55^{\prime} \mathrm{N}$, 2303'09'”, vid. P. Chmielewski, 01.08.2009. 


\section{Orobanche alsatica Kirschl.}

The species prefers warm hazel scrub of the Peucedano cervariae-Coryletum association and xerothermic oak forests of the Potentillo albae-Quercetum association, on shallow chalky rendzinas. It is rarely recorded in open xerothermic grasslands of the Cirsio-Brachypodion pinnati alliance. Numerous populations of the species are rare and its abundance may fluctuate from one year to another. It flowers in June and July. Peucedanum cervaria is the host of $O$. alsatica in the study area (Fig. 2).

List of localities: DG: 1. Orłów Murowany - forest complex, Peucedano cervariae-Coryletum association, on the slope of a calcareous hill, ca. $1 \mathrm{~km} \mathrm{E}$ of the village $(<10)$, GE6238, 5054'26’N, 23¹4’26”, leg. P. Chmielewski \& R. Piwowarczyk, 11.07.2008 (KTC); 2. Broczówka SW-facing slopes on chalky rendzinas in the Inuletum ensifoliae association with accompanying Peucedano cervariae-Coryletum scrub, in the steppe "Broczówka" reserve, ca. $1.5 \mathrm{~km} \mathrm{~N}$ of Skierbieszów $(<100)$, GE6377, $50^{\circ} 52^{\prime} 05^{\prime} \mathrm{N}, 2^{\circ} 22^{\prime} 05^{\prime} \mathrm{E}$, leg. R. Piwowarczyk, W. Michalczuk \& P. Chmielewski, 08.06.2005 (KTC); leg. A. Cwener, 2006 (LBL), leg. R. Piwowarczyk, 15.07.2006 (KTC); 3. Czechówka - an overgrowing Inuletum ensifoliae xerothermic grassland on chalk and Peucedano cervariae-Coryletum scrub, in a midforest glade in the forest complex by the Grabowiec - Wojsławice road $(<50)$, GE6489, 5051'17'N, 2332'08'E, leg. A. Cwener, 02.07.2006, (LBL); OB: 4. Horeszkowice - a midforest glade, ca. $3 \mathrm{~km} \mathrm{SE}$ of the buildings in the village, in the vast Lasy Strzeleckie forest complex, in Peucedano cervariae-Coryletum scrub in oak-hornbeam and swamp forests $(<30)$, GE5679, 5056’21'N, 2349'28’'E, leg. J. Wójciak \& R. Piwowarczyk, 12.07.2008 (KTC); PC: 5. Wolwinów - "Wolwinów" reserve, near the entry to Chełm, by the Hrubieszów - Chełm road. One specimen was recorded here in 2007 among the vegetation of the Peucedano cervariae-Coryletum association, GE3486,

Fig. 2. Distribution of: a - Orobanche alsatica, $\mathrm{b}-O$. arenaria, $\mathrm{c}-O$. pallidiflora in SE Poland.
5106'59”N, 2330'49”E, vid. R. Piwowarczyk \& P. Chmielewski, 08.06.2007 (KTC); PZ: 6. Kąty II - a midfield hill known as Wieprzecka Góra, in Peucedano cervariae-Coryletum scrub, on chalky rendzina $(<20)$, GE8291, 5040'33'N, 2307'22”E, leg. R. Piwowarczyk, W. Michalczuk \& P. Chmielewski, 13.07.2006 (KTC); 7. Dąbrowa near Łabunie - "Labunie" reserve in a glade on the forest edge, ca. $1 \mathrm{~km}$ SE of the village buildings, scrub of the Peucedano cervariae-Coryletum association and in the termophilous oak forest (Potentillo albae-Quercetum), on chalky rendzina $(<30)$, GE9402, 50³9'10"N, 2324'56”E, leg. P. Chmielewski \& R. Piwowarczyk, 12.07.2007, 13.07.2008 (KTC); RŚ: 8. Majdanek between Majdan Górny and Justynówka villages, on the Sand SW-facing vast calcareous slope of the "Biała Góra" ecological site, in the vegetation of the Peucedano cervariae-Coryletum association and fringe communities of the Trifolio-Geranietea sanguinei class $(<50)$, GF1407, 50²8'33"N, 2328'44"E, leg. P. Chmielewski \& R. Piwowarczyk, 13.07.2006 (KTC), leg. R. Piwowarczyk, 28.06.2008 (KTC).

\section{Orobanche arenaria Borkh.}

The species is very rare in Poland, it has so far been confirmed or reported as occurring at only four localities: in Lower Silesia (Szczęśniak 2003) and in the Niecka Nidziańska basin (Piwowarczyk and Przemyski 2010). It was recorded at one locality in the Middle Vistula Gap in the study area (Fig. 2). It flowers at the end of June and the beginning of July. It parasitizes Artemisia campestris.

List of localities: MPW: Męćmierz - the N and NEfacing slope of a small dry valley, ca. $1.5 \mathrm{~km} \mathrm{SW}$ of the village, a fallow field with dominant vegetation of the class Artemisietea vulgaris (>100), FE2323, 51 $18^{\prime} 07^{\prime} \mathrm{N}$, 21 ${ }^{\circ} 53^{\prime}$ 54'E, vid. P. Chmielewski, 22.04.2009, leg. R. Piwowarczyk, 26.07.2009 (KTC).

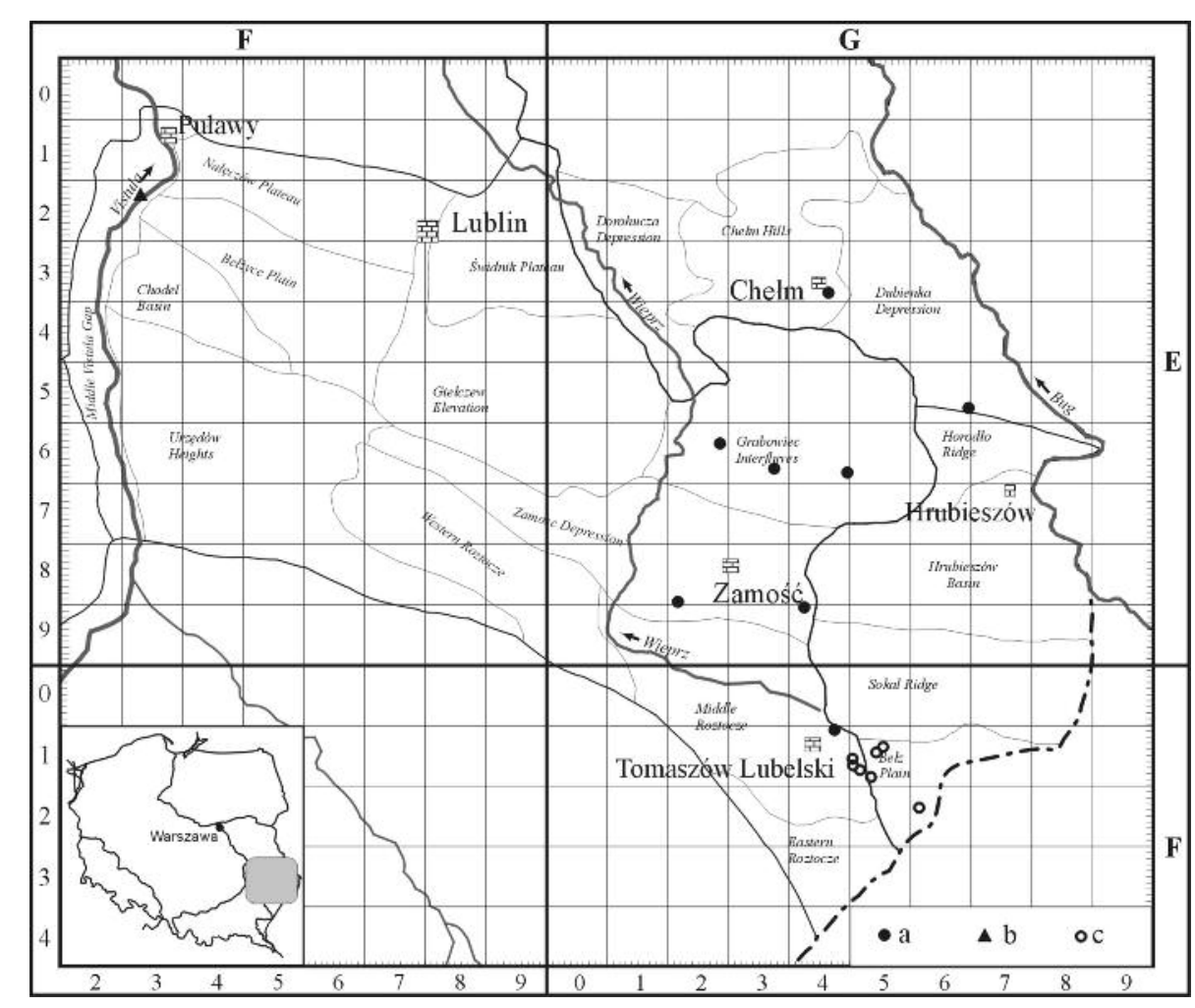




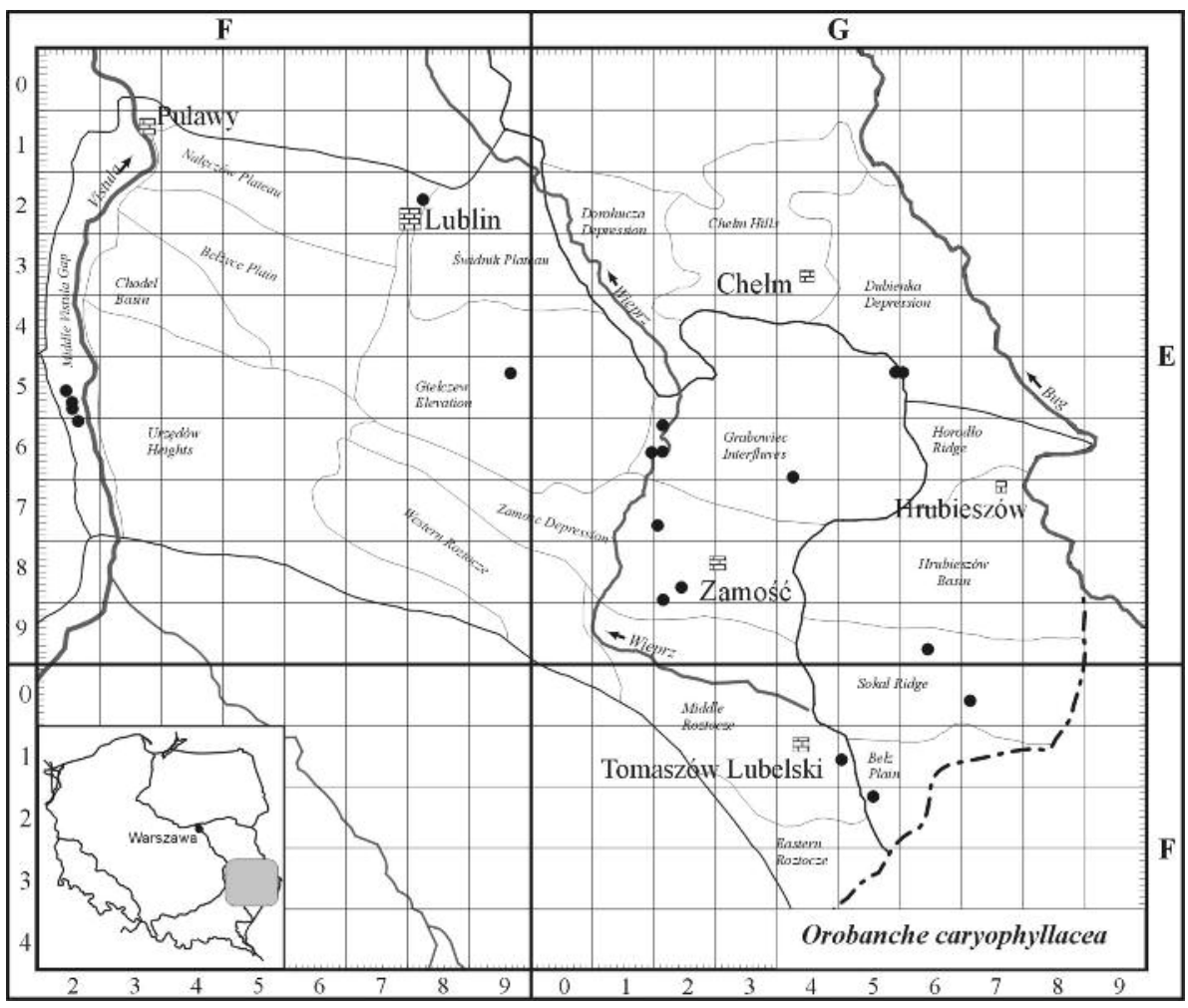

Fig. 3. Distribution of Orobanche caryophyllacea in SE Poland.

\section{Orobanche caryophyllacea Sm.}

The species is recorded on sun-exposed slopes on calcareous or loess substrate. It prefers open sites where it colonizes xerothermic grasslands of Cirsio-Brachypodion pinnati alliance. It rarely forms larger populations. It flowers from May until the end of June. It parasitizes Galium mollugo and sporadically G. verum (Fig. 3).

List of localities: DG: 1. Tarnogóra - grasslands belonging to Thalictro-Salvietum pratensis association in the escarpment complex in the Wieprz valley $(>15)$, GE6159, GE6251, 5053'47'N, 2307'10”E, leg. A. Cwener, 24.06.2008 (LBL); 2. Hajowniki (Reforma) xerothermic grasslands and scrubs on the chalky slope of the Wolica river, on the northern side of the Skierbieszów Grabowiec road (>50), GE6492, 5050'26”N , 2326’35'E, leg. A. Cwener, 22.06.2007 (LBL); 3. Kolonia Teresin xerothermic grasslands and roadsides on chalky rendzinas on a hill ca $0.5 \mathrm{~km} \mathrm{~S}$ of the village ( $>50)$, GE5529, GE5620, $50^{\circ} 59^{\prime} 21^{\prime \prime} \mathrm{N}, 23^{\circ} 41^{\prime} 56^{\prime \prime} \mathrm{E}$; 50 $59^{\circ} 14^{\prime \prime} \mathrm{N}, 23^{\circ} 42^{\prime} 20^{\prime \prime} \mathrm{E}$;

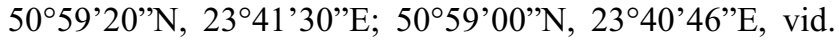
P. Chmielewski, A. Cwener \& R. Krawczyk, 2005, leg. P. Chmielewski \& R. Piwowarczyk, 15.07.2006 (KTC); 4. Dworzyska - E-facing steep slopes of the Wieprz valley, an overgrowing Thalictro-Salvietum pratensis grassland $(<20)$, GE6211, 5055'47'N, 2308'38'E, leg. A. Cwener, 09.06.2008 (LBL); GS: 5. Dobużek - "Skarpa Dobużańska" reserve, ca. $1 \mathrm{~km} \mathrm{NW}$ of the Dobużek village, on the steep slope of the Huczwa river valley, xerothermic grasslands belonging to Thalictro-Salvietum pratensis association, on chalky rendzina and chernozems ( $>50)$, GE9674, 50³4'50’'N, 2342'55'E, leg. P. Chmielewski \& R. Piwowarczyk, 12.07.2006 (KTC); 6. Posadów - xerothermic grassland on embankments of an early medieval earthwork, on the edge of the Kamionka river valley, ca. $0.5 \mathrm{~km} \mathrm{~N}$ of the village (>30), GF0751, 50³0'27'N, 2348'57'E, vid. E. Gorgol \& P. Chmielewski, 24.05.2009; MPW: 7. Ciszyca Kolonia - a xerothermic grassland on chalky ren- dzina, belonging to Cirsio-Brachypodion pinnati aliance, and in thermophilous scrub of the Trifolio-Geranietea sanguinei and Rhamno-Prunetea classes on the slope of the Vistula valley, W of the road to Ciszyca Górna $(>100)$, FE5254, 51 01 '14'N, 2146'41'E, vid. R. Piwowarczyk, 2000-2008; leg. R. Piwowarczyk, 2000, 2006 (KTC), [the species also grows along a valley border in the PI (Piwowarczyk 2010b)]; 8. Dorotka - xerothermic grasslands and scrub on the slopes of the Vistula valley $(>30)$, FE5275, FE5285, 5059'57'N, 21 47'09'E, vid. R. Piwowarczyk, 2000-2007; leg. R. Piwowarczyk, 18.06.2006 (KTC), [the species also grows along a valley border in the PI (Piwowarczyk 2010b)]; 9. Wesołówka - the border between the Middle Vistula Gap and the Iłża Foreland (Bróż et. al. 2001; Piwowarczyk 2006, 2010b), in the SE part of the village, called "Modrzywka" by local residents, xerothermic grasslands and fallows fields on chalky rendzina (>15), FE6206, 5058'37'N, 21 47'49'E, vid. R. Piwowarczyk, 1999-2006; leg. R. Piwowarczyk, 2006 (KTC). The species did not occur in the period 2008-2010; PŚ: 10. Lublin - a grassland belonging to ThalictroSalvietum pratensis association on a high baulk on the slope of the Bystrzyca valley (>10), FE2842, 51 $16^{\prime} 23^{\prime \prime} \mathrm{N}$, 22 37'57'E, leg. A. Rysiak, 2006 (LBL); PZ: 11. Złojec a xerothermic grassland belonging to Thalictro-Salvietum pratensis association on a midforest hill in the Łabuńka river valley, ca. $300 \mathrm{~m} \mathrm{~N}$ of the village church $(>30)$, GE7270, 5046’55’N, 2307'12”E, vid. W. Michalczuk 17.06.2006; 12. Kąty II - xerothermic grasslands adjacent to a dirt road from the Wymysłówka village to Wychody, on a midfield hill known as Wieprzecka Góra $(>50)$, GE8291, 5040’22”N, 2307'22”E, leg. R. Piwowarczyk, W. Michalczuk \& P. Chmielewski, 15.07.2006 (KTC); 13. Hubale - xerothermic grassland on a calcareous hill, ca. $0.5 \mathrm{~km} \mathrm{~N}$ of the village $(>15)$. The locality was partly damaged by ploughing in 2009. GE8274, 50 41'07'N, 2309'47’E, vid. W. Michalczuk, 2007; RB: 14. Machnów 
Stary - overgrowing xerothermic grasslands in the "Machnowska Góra" reserve (>10), GF2515, 50²2’06”N, 2335'18”'E, vid. P. Chmielewski \& R. Piwowarczyk, 13.07.2006; RŚ: 15. Przeorsk - xerothermic grassland on the Łysa Góra hillside and on the bottom of a dry small valley joining the Sołokija river $(>50)$, GF1550, 50²5'27'N, 23 31'06”'E, leg. P. Chmielewski \& R. Piwowarczyk, 09.06.2007 (KTC); WG: 16. Kolonia Żuków near Krzczonów - a partly forested xerothermic grassland near a closed limestone quarry. The site is protected as part of the "Kamienny Wąwóz" nature and landscape complex (>5), FE5926, 51 02 ' $15^{\prime \prime} \mathrm{N}$, 22॰47’40”'E, vid. P. Chmielewski, 17.08.2009.

\section{Orobanche elatior Sutton}

The species is recorded in highly sun-exposed xerothermic and mesoxerothermic grasslands, on baulks and roadsides and the edges of arable lands, on shallow chalky rendzinas and loess, less frequently on chernozems. It prefers grasslands belonging to Thalictro-Salvietum pratensis and Inuletum ensifoliae associations and initial calcareous communities. It rarely forms larger populations. It flowers from June to early August (September). Centaurea scabiosa is the host of O. elatior (Fig. 4).

List of localities: DG: 1. Żmudź - xerothermic grasslands and scrub in the "Żmudź" reserve and along its borders, ca. $0.5 \mathrm{~km}$ W of Kolonia Żmudź (>10), GE5508, 51 ${ }^{\circ} 00^{\prime} 29^{\prime \prime} \mathrm{N}, 2^{\circ} 40^{\prime} 27^{\prime} \mathrm{E}$, leg. R. Piwowarczyk \& P. Chmielewski, 08.06.2007 (KTC); 2. Wólka Leszczańska a narrow belt of xerothremic grasslands between the "Żmudź" reserve and the village (>5), GE4595, $51^{\circ} 00^{\prime} 41^{\prime \prime} \mathrm{N}, 23^{\circ} 39^{\prime} 09^{\prime} \mathrm{E}$, leg. P. Chmielewski \& R. Piwowarczyk, 08.06.2008 (KTC); 3. Podlesie - a xerothermic grassland and blackthorn scrub, ca. $1 \mathrm{~km} \mathrm{~S}$ of Wólka Leszczańska (>20), GE5516, 5100'03"N, $23^{\circ} 39^{\prime} 03^{\prime \prime}$ E, vid. P. Chmielewski, 2007; 4. Leszczany - a fallow field and an arable field adjacent to a former limestone excavation pit, by the Żmudź - Kumów Majoracki road, near village buildings $(<50)$. Some specimens were deformed, probably following treatment with weed killers. GE4591, 5101'29"N, 2334'53"E, leg. P. Chmielewski \& R. Piwowarczyk, 09.06.2007 (KTC); 5. Huszczka Duża - xerothermic grasslands belonging to Inuletum ensifoliae association and in communities with Brachypodium pinnatum, on a vast calcareous slope $(<15)$, GE7304, 50॰50'10"N, 2319'11"E, leg. A. Cwener, 30.06.2006 (LBL); 6. Wolica Uchańska - a xerothermic grassland and a fallow field on cretaceous rendzina on a W-, SW- and S-facing slope, by the Skierbieszów Grabowiec road, immediately behind Wolica Uchańska (>30), GE7416, 5049'36”N, 2329'29'"E, leg. A. Cwener, 27.07.2006 (LBL), vid. P. Chmielewski, 2008; 7. Kolonia Łaziska - a degraded xerothermic grassland on a S- and SW-facing slope, ca. $400 \mathrm{~m}$ E of the village (>20), GE7430, $50^{\circ} 48^{\prime} 42^{\prime \prime} \mathrm{N}, 23^{\circ} 24^{\prime} 05^{\prime} \mathrm{E}$, leg. A. Cwener, 29.05.2005, vid. P. Chmielewski, 2007; 8. Kolonia Teresin - roadsides, fallow fields, xerothermic grasslands and loose blackthorn scrub on a vast calcareous scrub ca. $0.5 \mathrm{~km} \mathrm{~S}$ of the village (>30), GE5529, GE5539, GE5620, GE5630, 5059'41'”N, $23^{\circ} 40^{\prime} 54^{\prime \prime} \mathrm{E} ; 50^{\circ} 58^{\prime} 43^{\prime \prime} \mathrm{N}, 23^{\circ} 41^{\prime} 57^{\prime \prime} \mathrm{E}$; 50 59'19”N,

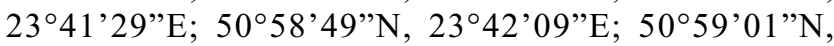
$23^{\circ} 41^{\prime} 11^{\prime \prime} \mathrm{E} ; 50^{\circ} 58^{\prime} 46^{\prime \prime} \mathrm{N}, 23^{\circ} 41^{\prime} 25^{\circ} \mathrm{E} ; 50^{\circ} 59^{\prime} 20^{\prime \prime} \mathrm{N}$, $23^{\circ} 42^{\prime} 00^{\prime \prime E}$, leg. P. Chmielewski \& R. Piwowarczyk, 08.06.2007 (KTC); 9. Tarnogóra - xerothermic grassland of Thalictro-Salvietum pratensis association on a loess slope (>5), GE6240, 5053'42'N, 2308'09'E, vid. A. Cwener, 2007; 10. Turowiec - a vast complex of initial xerothermic grasslands and juniper scrub, ca. $1.5 \mathrm{~km} \mathrm{~N}$ of the cemetery near Turowiec - Popówka villages $(<5)$, GE5556, 5058'00”N, 2338'12'E, vid. P. Chmielewski 2007, 11. Rogów - xerothermic grasslands belonging to Inuletum ensifoliae association in the "Rogów" reserve, on the calcareous slope of a water course, ca. $1 \mathrm{~km} \mathrm{SE}$ of the

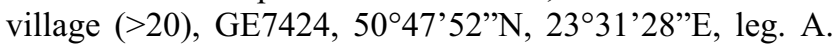

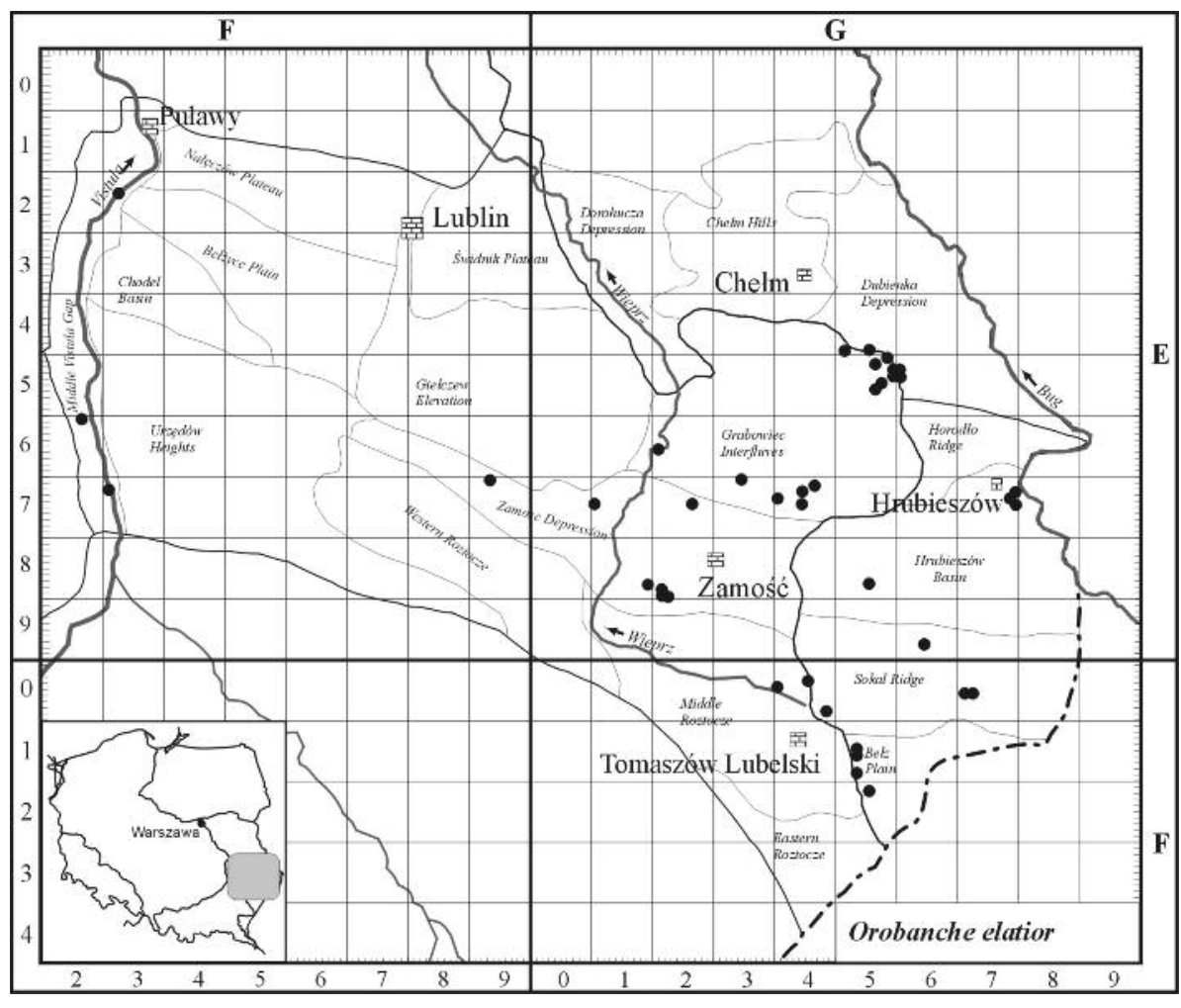

Fig. 4. Distribution of Orobanche elatior in SE Poland. 
Cwener, 02.07.2006 (LBL); 12. Żuków - a degraded xerothermic grassland on a cretaceous slope $(>20)$, GE7444, 5047'51'N, 2328'09'E, leg. A. Cwener, 20.07.2006 (LBL); 13. Maziarnia - roadsides on the edge of a forested xerothermic scrub complex, ca. $300 \mathrm{~m} \mathrm{~S}$ of Maziarnia near Putnowice ( $>20)$, GE5547, 5058'32'N, 2339'13”'E, vid. P. Chmielewski, 25.04.2009; GS: 14. Posadów - xerothermic grasslands belonging to ThalictroSalvietum pratensis association, on cretaceous rendzina and chernozems, $0.5 \mathrm{~km} \mathrm{~N}$ of the village, on the edge of the Kamionka river valley, on both sides of the road to Telatyn (>30), GF0751, GF0752, 50³0'27'N, 2348'57' E;

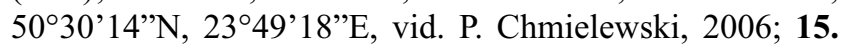
Dobużek - "Skarpa Dobużańska" reserve, ca. $1 \mathrm{~km} \mathrm{NW}$ of the village, a xerothermic grassland belonging to ThalictroSalvietum pratensis association on the steep slope of the Huczwa river valley (>20), GE9674, 50³4'50"N, 2342'56”'E, leg. P. Chmielewski \& R. Piwowarczyk, 14.07.2006 (KTC); 16. Przecinka - xerothermic grassland on a chalky hillside (Góra Kamienna), between Przecinka and Justynówka villages (>20), GF0488, 50²9'22"N, 2329'37'”, vid. P. Chmielewski, 15.06.2008; KH: 17. Kazimierówka - the side of the road from the Kotlice village towards Perespa, ca. $300 \mathrm{~m} \mathrm{~S}$ of the Kotlice Forest. Over ten specimens of $O$. elatior were recorded in 2007; the species was not observed afterwards although the habitat did not change. GE8575, 5040'35'N, 2336'27'E, vid. P. Chmielewski, 2007; 18. Gródek - xerothermic grasslands on the slopes of the Bug valley stretching from the Kolonia Gródek village towards Czumów ( $>50)$, GE7729, GE7738, GE7749, 5047'46”N, 2357'11'E; $50^{\circ} 46^{\prime} 57^{\prime} \mathrm{N}, 2^{\circ} 56^{\prime} 47^{\prime} \mathrm{E}$, leg. P. Chmielewski \& A. Cwener, 28.06.2008; MPW: 19. Opoka Duża - a fallow field bordering on the steep slopes of the Vistula valley, overgrown with dense thermophilous scrub, ca. $1 \mathrm{~km} \mathrm{NW}$ of the village $(<5)$, FE7310, 50 $51^{\circ}$ '58'N, 21 ${ }^{\circ} 51^{\prime} 23$ 'E, vid. P. Chmielewski, 14.04.2009; 20. Wesołówka near Tarłów, the borderline between MPW and PI (Piwowarczyk 2006, 2010b) - fallow fields, baulks and xerothermic grasslands along the edge of the Vistula valley, in the part of the village known as "Modrzywka" (>30), FE6206, 5058'41'N, 2147'47’'E, vid. R. Piwowarczyk, 1999-2010; leg. R. Piwowarczyk, 29.06.2005 (KTC); 21. Męćmierz xerothermic grassland on the slopes of a vast ravine (one specimen), FE2321, 51 $18^{\prime} 07^{\prime} \mathrm{N}, 21^{\circ} 54^{\prime} 02^{\prime}$ E, vid. P. Chmielewski \& R. Piwowarczyk, 26.07.2009; PZ: 22. Niedzieliska - fringe communities on the edge of a juniper scrub complex, ca. $700 \mathrm{~m} \mathrm{~S}$ of the village buildings (one specimen), GE8179, 5042'00'N, 2304'53'E, vid. A. Cwener \& P. Chmielewski, 28.07.2009; 23. Elizówka midfield initial xerothermic grasslands and scrub on hillsides, ca. $0.5 \mathrm{~km}$ of the village buildings (two specimens), FE7903, 5051'37'N, 2244'07''E, vid. P. Chmielewski \& R. Piwowarczyk, 2008; 24. Gruszka Duża - a narrow belt of a xerothermic grassland by the roadside, ca. $1 \mathrm{~km} \mathrm{~N}$ of the village (>15), GE7140, 50॰49'10'N, 22 ${ }^{\circ} 58^{\prime} 41^{\prime \prime} \mathrm{E}$, vid. P. Chmielewski, 2008; 25. Chomęciska Małe - a xerothermic grassland on a hillside, ca. $0.5 \mathrm{~km} \mathrm{SE}$ of the village buildings, at an intersection of field roads $(<5)$, GE7247, $50^{\circ} 48^{\prime} 26^{\prime \prime} \mathrm{N}, 23^{\circ} 12$ '34"E, vid. P. Chmielewski \& R. Piwowarczyk, 09.06.2007; 26. Kąty II - initial xerothermic grasslands near a dirt road from the Wymysłówka village to Wychody, on a midfield hill known as Wieprzecka Góra
$(<20), \quad$ GE8281, GE8291, GE8292, 5040’46”N,

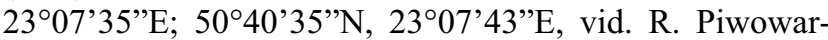
czyk, W. Michalczuk \& P. Chmielewski, 2006; RB: 27. Kolonia Korhynie - a fallow field on chalky rendzina, in the $\mathrm{W}$ part of the village. The locality was destroyed by ploughing in the spring 2010. GF1553, 50²5'41' $\mathrm{N}$, 2333'02"E, leg. P. Chmielewski \& R. Piwowarczyk, 13.07.2008 (KTC); 28. Kolonia Jarczów I - a fallow field in the $\mathrm{W}$ part of the village, by the road running $\mathrm{S}$ towards the Kolonia Korhynie village $(<10)$, GF1543, 50²6'03'N, $23^{\circ} 33^{\prime} 46^{\prime \prime} E$, vid. P. Chmielewski, 2008; 29. Żurawce - an initial xerothermic grassland near the "Żurawce" ecological site, on the slope of the Sołokija valley $(>20)$, GF1583, 50²3'33'N, 2333'35'E, vid. P. Chmielewski, 2007; 30. Machnów Stary - xerothermic grasslands in the "Machnowska Góra" reserve (>30), GF2515, 50²2'10"N,

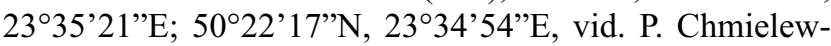
ski, 2007; RŚ: 31. Tarnawatka-Tartak - fallow fields and the roadside of a field road over the hill from Tarnawatka $S$ towards the Pańków village (>20), GF0440, 50³1'28'N, 2329'37'E, vid. P. Chmielewski, 27.07.2007, 32. Huta Tarnawacka - an initial xerothermic grassland on the SW and $\mathrm{S}$ hillsides, ca. $0.5 \mathrm{~km} \mathrm{~N}$ of the village, by a dirt road towards the Pauczno village ( $>50)$, GF0435, 50 32'05'N, 2329'37'E, vid. P. Chmielewski, 14.07.2006.

\section{Orobanche lutea Baumg.}

$O$. lutea prefers xerothermic grasslands, fringe communities and fallow fields, mostly on shallow chalky rendzinas. It accompanies communities belonging to the Cirsio-Brachypodion pinnati alliance, the Trifolio-Geranietea sanguinei and Rhamno-Prunetea classes, where it often forms very large populations. It is sporadically recorded in Sisymbrio-Stipetum capillatae. It flowers in May and June. The species parasitizes Medicago falcata, sporadically also $M$. sativa. It is mostly recorded among species of the genus Orobanche in the study area (Fig. 5).

List of localities: DG: 1. Żmudź - initial xerothermic grasslands and scrub in the "Żmudź" reserve, ca. $0.5 \mathrm{~km} \mathrm{~W}$ of Kolonia Żmudź (>200), GE4597, 5100'33”N, 2340'26”E, leg. R. Piwowarczyk \& P. Chmielewski, 08.06.2007 (KTC); 2. Wólka Leszczańska - a xerothermic grassland between the "Żmudź" reserve and Wólka Leszczańska (>15), GE4595, 51 ${ }^{\circ} 00^{\prime} 40^{\prime \prime} \mathrm{N}, 23^{\circ} 39^{\prime} 09^{\prime \prime} \mathrm{E}$, leg. P. Chmielewski \& R. Piwowarczyk, 08.06.2007 (KTC); 3. Kolonia Leszczany - thermophilous juniper scrub and fringe communities near the forest complex growing on the $\mathrm{W}$ slope of the Kurawica hill $(<50)$,

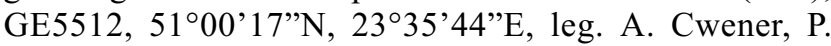
Chmielewski \& R. Piwowarczyk, 13.07.2007 (KTC); 4. Hajowniki - a degraded xerothermic grassland on the loess slope of the Wolica river valley, on the $\mathrm{S}$ side of the Skierbieszów - Grabowiec road, ca. $1 \mathrm{~km}$ before village buildings in Hajowniki (>20), GE7402, 5050'16”N, $23^{\circ} 25^{\prime} 50^{\prime \prime}$, , vid. P. Chmielewski, 10.05.2008; 5. Kolonia Teresin - fallow fields and mesoxerothermic grasslands on a vast hill, located ca. $0.5 \mathrm{~km} \mathrm{~S}$ of the village $(>20)$, GE5539, GE5620, GE5630, 5059'21'N, 2341'58”'E; $50^{\circ} 59^{\prime} 04^{\prime \prime} \mathrm{N}, 23^{\circ} 41^{\prime} 09^{\prime \prime} \mathrm{E}$; $50^{\circ} 58^{\prime} 48^{\prime} \mathrm{N}, 23^{\circ} 42^{\prime} 00^{\prime}$ 'E, leg. P. Chmielewski, 2007; 6. Kolonia Wygnańce - the roadside in the $\mathrm{N}$ part, in a juniper scrub complex (>10), GE5553, 5058'13”N, 2336'14”'E, vid. P. Chmielewski, 2008; 7. Turowiec - initial xerothermic grasslands and juniper 


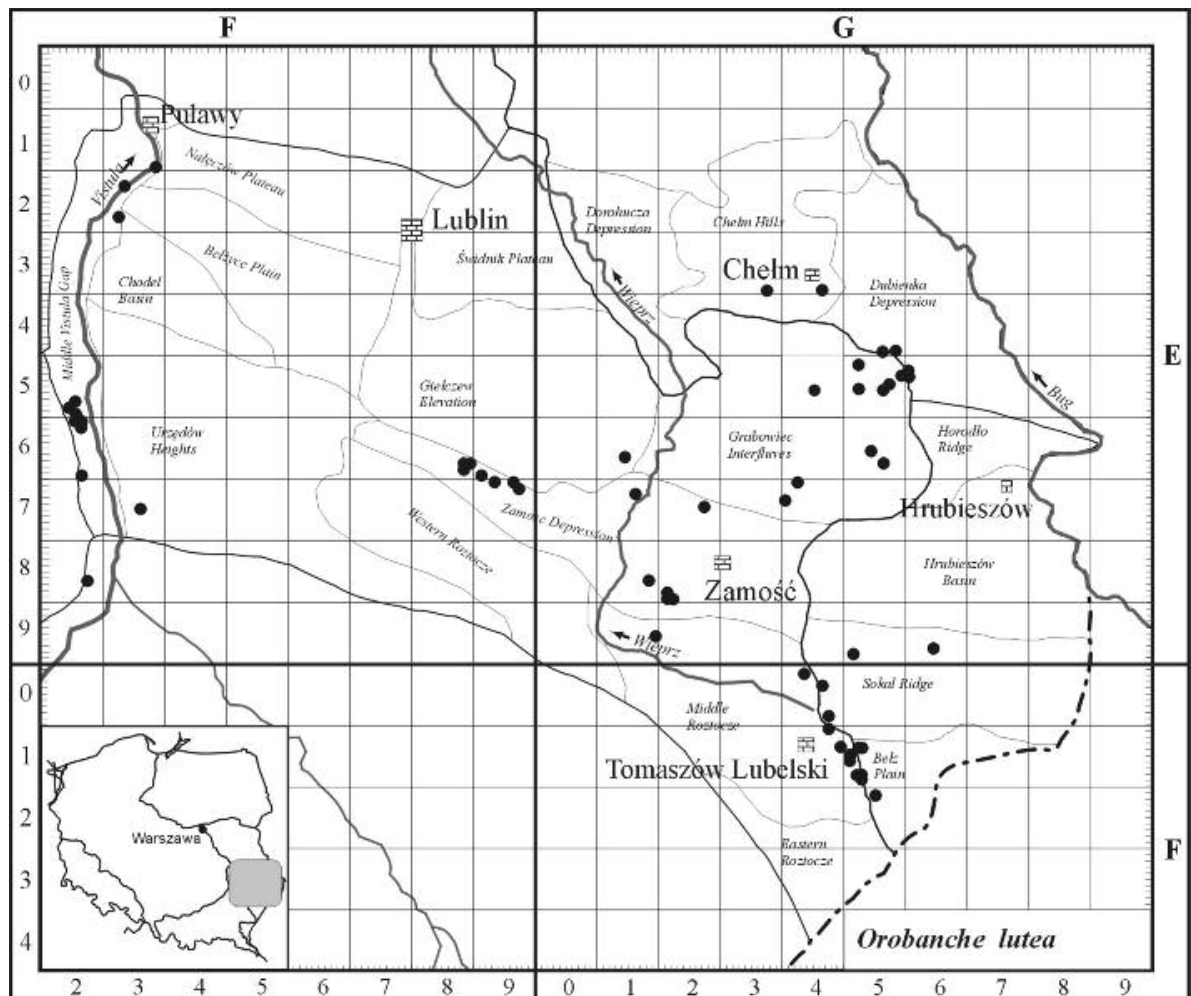

Fig. 5. Distribution of Orobanche lutea in SE Poland. scrub, ca. $1.5 \mathrm{~km} \mathrm{~N}$ of the cemetery near Turowiec Popówka villages (<5), GE5556, 5058'03'N, 2338'10”'E, vid. P. Chmielewski, 25.04.2009; 8. Maziarnia - forested complex of xerothermic grasslands and scrub, ca. $300 \mathrm{~m} \mathrm{~S}$ of the village (>10), GE5547, 5058'31'N, 2339'20'E, vid. P. Chmielewski, 04.07.2009; 9. Nowy Folwark xerothermic grassland, ca. $1.5 \mathrm{~km} \mathrm{E}$ of the village $(>5)$, GE5465, 5057'36”N, 2329'26’'E, vid. P. Chmielewski, 17.07.2009; 10. Kolonia Łaziska - degraded xerothermic grassland on a S- and SW-facing hillside, ca. $400 \mathrm{~m} \mathrm{E}$ of the village (>10), GE7430, 50॰48'42'N, 2324'00”, leg. A. Cwener, 29.07.06 (LBL); 11. Białowody - a xerothermic grassland on a hillside, ca. $400 \mathrm{~m} \mathrm{E}$ of the Grabowiec Uchanie road (>10), GE6554, 5052'34'N, 2336'52'E, vid. P. Chmielewski, 2008; 12. Gliniska - xerothermic grasslands and blackthorn scrub in the "Gliniska" reserve and on the calcareous slope of the Kalinówka river $(<50)$, GE6576, 5051'30”N, 2338'12”E; 5051'22”N, 2338'04”E, vid. P. Chmielewski, 2008; GS: 13. Huta Tarnawacka - a fringe community on the $\mathrm{S}$ border of a small forest complex located ca. $300 \mathrm{~m} \mathrm{~N}$ of the village buildings (>10), GF0436, 50³2'06”N, 2327'23”E, leg. P. Chmielewski, 2006, 14. Dobużek - xerothermic grasslands in the "Skarpa Dobużańska" reserve ca. $1 \mathrm{~km} \mathrm{NW}$ of the village, on the steep slope of the Huczwa river valley, on chalky rendzina and chernozems (>200), GE9674, 5034'49”N, 2342'44"E, leg. P. Chmielewski \& R. Piwowarczyk, 2008 (KTC); 15. Kozia Wola near Wożuczyn - a xerothermic grassland on the slope of a water course valley flowing into the Rachanka river, ca. $1 \mathrm{~km}$ NW of the village buildings (>15), GE9581, 50 34'41' N, $23^{\circ} 32^{\prime} 46^{\prime \prime}$, vid. P. Chmielewski, 2007; 16. Przecinka xerothermic grasslands, roadsides and fringe communities on the forest edge, ca. $300 \mathrm{~m} \mathrm{~N}$ of the $\mathrm{W}$ border of the Justynówka village (>30), GF0487, 50²9'15'N, 2328'23”'E, vid. P. Chmielewski, 2007; MPW: 17. Bochotnica xerothermic grasslands and scrub on a calcareous escarp- ment, ca. $150 \mathrm{~m} \mathrm{NE}$ of the school building (>30), FE1398, $51^{\circ} 20^{\prime} 28^{\prime} \mathrm{N}, 21^{\circ} 59^{\prime} 52^{\prime} \mathrm{E}$, leg. P. Chmielewski \& R. Piwowarczyk, 23.08.2008 (KTC); 18. Męćmierz xerothermic grasslands and fallow fields on a hill, ca. 300 $\mathrm{m} \mathrm{SW}$ of the village buildings $(>30)$, FE2323, $51^{\circ} 18^{\prime} 25^{\prime \prime} \mathrm{N}$, 21 ${ }^{\circ} 54^{\prime} 28^{\prime \prime}$ E, leg. P. Chmielewski \& R. Piwowarczyk, 23.08.2008 (KTC); 19. Dobre - xerothermic grassland and a fallow field on the S side of the Kazimierz Dolny Dobre road, ca. $0.5 \mathrm{~km}$ from the village buildings $(>5)$,

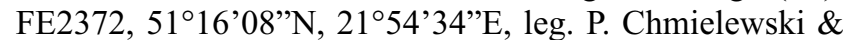
R. Piwowarczyk, 23.08.2008 (KTC); 20. Dorotka xerothermic grasslands and scrub as well as fallow fields and roadsides in the $\mathrm{S}$ and SE part of the village, along the edge and on the slopes of the Vistula valley, by a field road towards Sulejów $(<200), \quad F E 5275,50^{\circ} 59^{\prime} 56^{\prime} \mathrm{N}$, $21^{\circ} 47^{\prime} 11^{\prime \prime}$, vid. R. Piwowarczyk, 2000 - 2008, leg. R. Piwowarczyk, 01.06.2002 (KTC), [the species also grows along a valley border in the PI (Piwowarczyk 2010b)]; 21. Wesołówka - xerothermic grasslands, thermophilous scrub, ecotone zones with arable and fallow fields on chalky rendzina, along the edge and on the slopes of the Vistula valley, on the border with the PI (Piwowarczyk 2006, $2010 \mathrm{~b}$ ), in the NE part of the village, towards Sulejów $(<400)$, FE6205, FE6206, FE6216, 50 58'49”N, $21^{\circ} 47^{\prime} 47^{\prime \prime} \mathrm{E} ; 50^{\circ} 58^{\prime} 56^{\prime} \mathrm{N}, 47^{\circ} 38^{\prime} 73^{\prime \prime} \mathrm{E} ; 50^{\circ} 58^{\prime} 27^{\prime} \mathrm{N}$, $21^{\circ} 47^{\prime} 48^{\prime \prime}$, vid. R. Piwowarczyk, 1999-2009, leg. R. Piwowarczyk, 1999, 2008 (KTC); 22. Sulejów - xerothermic grasslands with numerous juniper plants, in thermophilous scrub, on baulks and sides of field roads on chalky rendzina, on the edge and the slopes of the Vistula valley, in the $\mathrm{N}$ and $\mathrm{S}$ part of the village $(<100)$, FE5284,

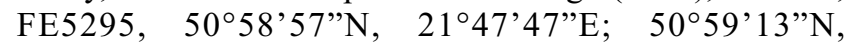
$21^{\circ} 47^{\prime} 41^{\prime \prime} E$, vid. R. Piwowarczyk, 2000-2008, leg. R. Piwowarczyk, 2000, 2007 (KTC); 23. Biedrzychów - the edge of a fallow field and thermophilous scrub on chalky rendzina, $\mathrm{N}$ of the road to Lasocin $(>10)$, FE6296, $50^{\circ} 54^{\prime} 05^{\prime} \mathrm{N}, 21^{\circ} 47^{\prime} 13$ 'E, leg. R. Piwowarczyk, 2008 
(KTC); 24. Słupcza - on the border with WS, xerothermic grassland on loess belonging to Sisymbrio-Stipetum capillatae association, on the S-facing slope of the Vistula valley, known as "Panieńska Góra", in an ecological site bordering on the railway track to the E $(>15)$, FE8267,

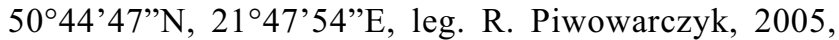
2008 (KTC); PC: 25. Zawadówka near Chełm - a hill surrounded by a marl peat bog in the "Torfowisko Sobowice" reserve, ca. $0.5 \mathrm{~km} \mathrm{~W}$ of the village $(<15)$,

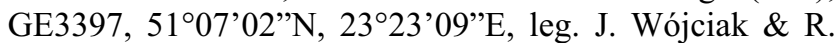
Piwowarczyk, 12.07.2008 (KTC); 26. Wolwinów - fringe communities and roadsides on the edge of a forest complex in the "Wolwinów" reserve (>20), GE3496, 51 ${ }^{\circ} 06^{\prime} 46$ "N, 2330'41'E, leg. R. Piwowarczyk \& P. Chmielewski, 08.06.2007 (KTC); PZ: 27. Nowy Dwór - fallow fields, roadsides, fringe communities and fragmentary patches of xerothermic grasslands on the "Biała Góra" slopes, ca. 1.5 $\mathrm{km} \mathrm{N}$ of the village $(>100)$, FE6879, FE6878, FE6888,

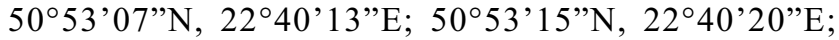
5053'09'N, 22 39'59'E, leg. P. Chmielewski \& R. Piwowarczyk, 11.07.2008 (KTC); 28. Guzówka - fringe communities on the edge of a forest complex, ca. $0.5 \mathrm{~km} \mathrm{~N}$ of the village (>10), FE6991, 50॰52'16"N, 22॰42'31'"E, vid. P. Chmielewski \& R. Piwowarczyk, 11.07.2008; 29. Elizówka - midfield initial grasslands and xerothermic scrub on a hillside, ca. $0.5 \mathrm{~km}$ of the village buildings (>50), FE7903, 50॰51'35”N, 22॰44'11'”E; 50॰51'16”N, 22 44'02'E, vid. P. Chmielewski \& R. Piwowarczyk, 11.07.2008; 30. Żabno - two populations; one population in a xerothermic grassland in a limestone excavation pit, by the Żabno - Żółkiewka road, ca. $0.5 \mathrm{~km}$ of the village $(>15)$, the other ca. $1 \mathrm{~km} \mathrm{SE}$ of the first, in a midfield xerothermic grassland $(>20)$, FE7906, FE7917, 50 51'38'N,

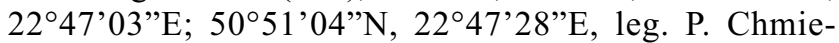
lewski \& R. Piwowarczyk, 09.06.2007 (KTC); 31. Chomęciska Małe - xerothermic grasslands, fallow fields and alfalfa cultivation on a hillside, ca. $0.5 \mathrm{~km}$ SE of the village

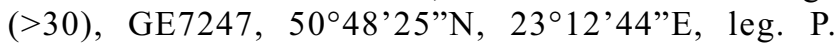
Chmielewski \& R. Piwowarczyk, 09.06.2007 (KTC); 32. Niedzieliska - xerothermic grasslands and thermophilous scrub with an abundant occurrence of juniper on a midfield hill, ca. $0.5 \mathrm{~km} \mathrm{~S}$ of the village $(>30)$, GE8168, $50^{\circ} 41^{\prime} 32^{\prime}$ N , 2304'23”'E, vid. P. Chmielewski, A. Cwener \& W. Michalczuk, 09.10.2008; 33. Kąty II - xerothermic grasslands on a midfield hill known as Wieprzecka Góra, neighbouring on a dirt road from the Wymysłówka village to Wychody (>100), GE8281, GE8291, GE8292, $50^{\circ} 40^{\prime} 22^{\prime} \mathrm{N}, 23^{\circ} 07^{\prime} 32^{\prime}$ E, leg. R. Piwowarczyk, W. Michalczuk \& P. Chmielewski, 02.06.2005, 2006 (KTC), leg. A. Cwener, 2007 (LBL). 34. Kolonia Staw Noakowski - a xerothermic grassland on the slope of the Wieprz valley, ca. $0.5 \mathrm{~km}$ SE of the village (>100), GE7126, 5049'48'N, 2304'11'E, vid. W. Michalczuk, 09.08.2006; RB: 35. Przewłoka - fringe communities in a midforest glade in a small forest complex, ca. $2 \mathrm{~km} \mathrm{~S}$ of the village $(>10)$, GF1532, 50²6'20”N, 2332’40”E, leg. P. Chmielewski \& R. Piwowarczyk, 13.07.2008 (KTC); 36. Kolonia Jarczów I - a fallow field in the $\mathrm{W}$ part of the village, by the road running $\mathrm{S}$ towards Kolonia Korhynie (>10), GF1533, 50²6'15”N, 2333'49”E, leg. P. Chmielewski \& R. Piwowarczyk, 13.07.2008 (KTC); 37. Kolonia Jarczów II - xerothermic grassland and alfalfa cultivations on the $\mathrm{SW}$ forest edge, ca. $1 \mathrm{~km} \mathrm{~S}$ of the village (>100), GF1573, 50²4'13”N, 23॰32'58'E, leg. P. Chmielewski \& R. Piwowarczyk, 12.07.2008 (KTC); 38. Korhynie - one population is located near the exit from the village, by the road towards Jarczów near a roadside shrine; the other population is located in the "Korhynie" ecological site, on the calcareous slope of the Sołokija river valley in a xerothermic grassland (>100), GF1572,

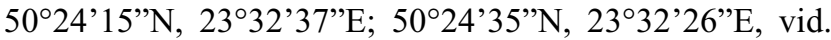
P. Chmielewski, 2008; 39. Żurawce - xerothermic grassland on the slope of the Sołokija valley, in the "Ź $\mathrm{u}$ rawce" ecological site (>100), GF1583, 50²3'43"N, $23^{\circ} 33^{\prime} 15^{\prime}$ E, vid. P. Chmielewski \& R. Piwowarczyk, 2007; 40. Machnów Stary - xerothermic grasslands in the "Machnowska Góra" reserve (>100), GF2515, 50²2’05’N, 23³5'14”E, leg. P. Chmielewski \& R. Piwowarczyk, 09.06.2007 (KTC); RŚ: 41. Kosobudy xerothermic scrub on a hillside, ca. $500 \mathrm{~m} \mathrm{~S}$ of the village

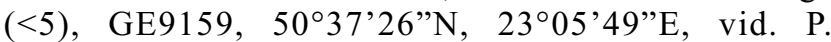
Chmielewski, 2008; 42. Huta Dzierążyńska - xerothermic grassland on the W-facing slope of the "Borowina" midfield hill, ca. $3 \mathrm{~km}$ SE of the village (>20), GF0413, $50^{\circ} 33^{\prime} 32^{\prime \prime} \mathrm{N}, 23^{\circ} 25^{\prime} 34^{\prime \prime} \mathrm{E}$, leg. P. Chmielewski \& R. Piwowarczyk, 15.07.2006 (KTC); 43. Majdanek - xerothermic grasslands and fringe communities on the S- and SW-facing slope of the "Biała Góra" ecological site, between Majdan Górny and Justynówka villages (>100), GF1407, 50²8'39'N, 2328’35'E, leg. P. Chmielewski \& R. Piwowarczyk, 13.07.2006 (KTC); 44. Ruda Wołoska xerothermic grassland on the $\mathrm{W}$ - and $\mathrm{SW}$-facing "Borowa Góra" slope, ca. $2 \mathrm{~km}$ NE of the village (>200), GF1439, 50²6’29’N, 2329'56”'E, vid. P. Chmielewski, 2008; 45. Przeorsk - xerothermic grasslands on the "Łysa Góra" slopes, on the S edge of the "Klimowice" forest, also on roadsides on chalky rendzina between Przeorsk and a former Przeorsk state farm (>150), GF1540, GF1550,

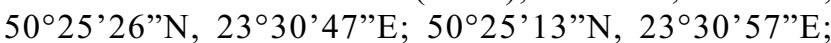
$50^{\circ} 25^{\prime} 48^{\prime \prime} \mathrm{N}, 23^{\circ} 31^{\prime} 06^{\prime \prime} \mathrm{E}$, leg. P. Chmielewski \& R. Piwowarczyk, 09.06.2007 (KTC); WG: 46. Bryczówki near Wirkowice - xerothermic grasslands near a closed limestone quarry (>50), GE6164, 5052'56”N $23^{\circ} 03^{\prime} 03^{\prime \prime}$, vid. R. Piwowarczyk \& W. Michalczuk, 15.07.2006; WU: 47. Wymysłów - pastures and fallow fields on a hillside, ca. $350 \mathrm{~m} \mathrm{E}$ of the village $(>50)$,

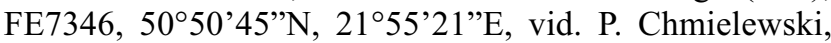
08.05.2009.

\section{Orobanche pallidiflora Wimm. \& Grab.}

The species colonizes sunny fallow fields, arable fields, meadows and ruderal communities on limestone and on clay formations. Individual populations are not numerous. The vegetative period of the species is exceptionally long and starts in mid June while flowering specimens were observed as late as in October. Cirsium arvense is the host of $O$. pallidiflora in the study area (Piwowarczyk et al. 2010) (Fig. 2).

List of localities: RB: 1. Kolonia Jarczów I - fallow fields, abandoned farms, roadsides in the $\mathrm{E}$ and $\mathrm{W}$ part of the village $(>10)$, GF1535, GF1544, 50 $26^{\prime} 13^{\prime} \mathrm{N}$,

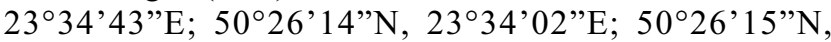
233 '57' E, leg. P. Chmielewski \& R. Piwowarczyk, 13.07.2008 (KTC), vid. P. Chmielewski, 20.08.2009; 2. Wierzbica near Machnów Nowy - on the edge of a weedy field cultivation bordering on moist meadows and pastures 
in the Sołokija river valley, by a dirt road ca. $1 \mathrm{~km} \mathrm{SW}$ of

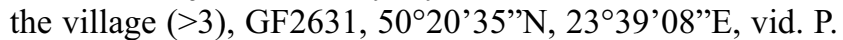
Stachyra, 2008, leg. P. Chmielewski, 2008; 3. Korhynie - a ruderal habitat in an abandoned farm on the village edge ( $>6$ in $2009,>30$ in 2010), GF1561, 50²4'39'N, 2331'53'"E, vid. P. Chmielewski, 21.08.2009, 07.09.2010; 4. Żurawce - a highly degraded xerothermic grassland with the dominance of ruderal vegetation, in the "Żurawce" ecological site $(>5$ in $2009,>10$ in 2010), GF1583, 50²3'49”N, 2333'19”E, vid. P. Chmielewski \& K. Barańska, 07.10.2009, vid. P. Chmielewski, 08.09.2010; RŚ: 5. Przeorsk (1) - a degraded, slightly moist meadow and a fallow field in the Sołokija river valley on the border with xerothermic grasslands and arable fields, by the road from Przeorsk towards Jarczów (>30), GF1550, 50²5’27’N, 2330'59'”, leg. P. Chmielewski \& R. Piwowarczyk, 09.06.2007 (KTC); 6. Przeorsk (2) - ca. 400 m E of the village buildings, on the SW slope of the Eysa Gora hill, in an arable field (four specimens in 2007, one specimen in 2008), GF1560, 50²5'14'N, 2330'59'E, leg. P. Chmielewski \& R. Piwowarczyk, 09.06.2007 (KTC).

\section{Orobanche picridis F. W. Schultz}

The species is included in the red data book as endangered (Zarzycki 2001). It parasitizes Picris hieracioides and is recorded only in highly sun-exposed initial calcareous communities, mostly in fallow fields and xerothermic grasslands where it often forms very large populations. It flowers from mid June to mid July (Fig. 6).

List of localities: MPW: 1. Wesołówka near Tarłów, the borderline between the PI and the MPW (Bróż et al. 2001; Piwowarczyk 2006, 2010b) - fallow fields, baulks, field edges and in initial xerothermic grasslands with a sparse field layer, on chalky rendzina, by the edge of the Vistula valley in the NE part of the village known as "Modrzywka" by local residents. $O$. picridis grows here in a few scattered populations. A total of 600 specimens were recorded. FE6206, 5058'39'N, 21 ${ }^{\circ} 47^{\prime} 44^{\prime \prime} \mathrm{E}$, vid. R. Piwowarczyk, 1999-2010; leg. R. Piwowarczyk, 1999, 2008 (KTC); 2. Dorotka - the locality borders on the PI (Piwowarczyk 2010b), SE part of the village, near a field road towards Sulejów $(>20)$, FE5275, 5059'56”N, 214'11'E, vid. R. Piwowarczyk, 2001-2006; leg. R. Piwowarczyk, 01.06.2002 (KTC); PZ: 3. Nowy Dwór fallow fields, roadsides, in fringe communities and fragmentary patches of xerothermic grasslands on the slopes of the "Biała Góra" hill, ca. $1.5 \mathrm{~km} \mathrm{~N}$ of the village (>500), FE6878, 5053'07”N, 22॰40'11”E, leg. P. Chmielewski \& R. Piwowarczyk, 11.07.2008; RB: 4. Zurawce - initial xerothermic grasslands on the slope of the Sołokija valley in the "Żurawce" ecological site (>300), GF1583, 50²3'37'N, 2333'24”E, leg. P. Chmielewski \& R. Piwowarczyk, 09.06.2007 (KTC); 5. Machnów Stary - fallow fields and initial xerothermic grasslands in the "Machnowska Góra" reserve $(>500)$, GF2515, 50²2'23”N, 2334'51'”, leg. P. Chmielewski \& R. Piwowarczyk, 09.06.2007 (KTC); RŚ: 6. Żurawnica near Zwierzyniec - fallow fields and roadsides on hillsides, ca. $2 \mathrm{~km}$ SE of the village buildings (>500), GE9131, GE9141, 50³8'27’N, 22॰58'56”E, leg. P. Chmielewski \& R. Piwowarczyk, 25.06.2008 (KTC); 7. Bliżów - fallow fields and fragments of mesoxerothermic grasslands, ca. 1 $\mathrm{km} \mathrm{N}$ of the village $(>50)$, GE9262, 50³6'23" $\mathrm{N}$, $23^{\circ} 07^{\prime} 37^{\prime}$ E, leg. W. Michalczuk \& R. Piwowarczyk, 16.07.2006 (KTC).

\section{CONCLUSIONS}

The list provides data on the occurrence of eight species belonging to the genus Orobanche: O. alba (21 localities), O. alsatica (8), O. arenaria (1), O. caryophyllacea (16), O.

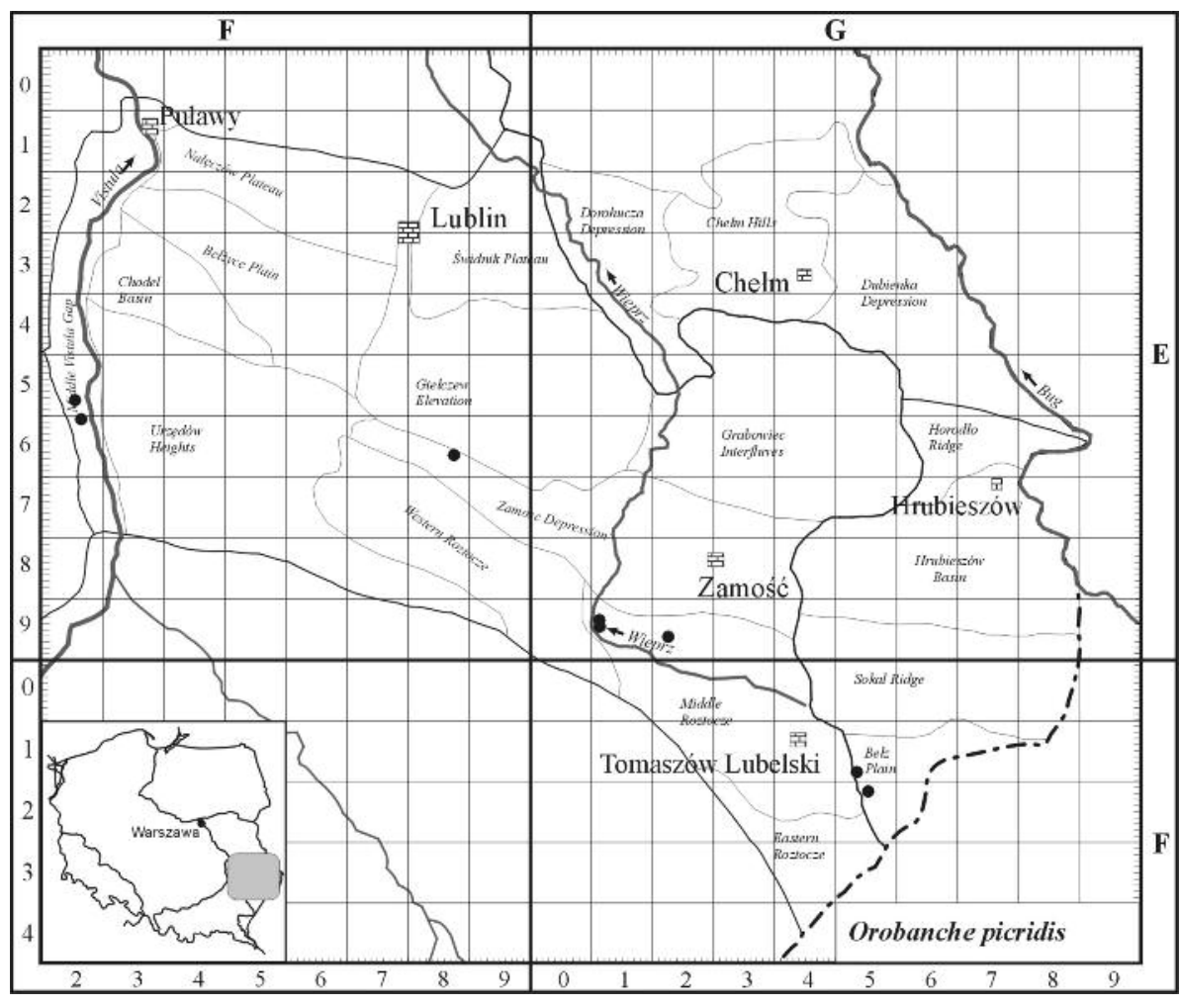

Fig. 6. Distribution of Orobanche picridis in SE Poland. 
elatior (32), O. lutea (47), O. pallidiflora (6), O. picridis (7). O. lutea as well as $O$. elatior and $O$. alba were the most frequently recorded species. $O$. arenaria, $O$. caryophyllacea, O. alsatica, O. picridis and $O$. pallidiflora were the least frequently recorded species. $O$. arenaria was reported from the area for the first time. The majority of Polish localities of $O$. alba and $O$. alsatica are situated here. $O$. coerulescens, $O$. purpurea and $O$. ramosa (Fijałkowski 1994) were not recorded despite efforts made to find them.

All of the taxa (except $O$. lutea) examined in the list are red listed (Zarzycki and Szeląg 2006) and one taxon, $O$. picridis, is included in the red data book (Zarzycki 2001).

The most abundant localities were recorded, for instance, in the Grabowiec Interfluves, Sokal Ridge, Bełz Plain, Zamość Depression or the Middle Vistula Gap. Many habitats preferred by species of the genus Orobanche can be found in these mesoregions: xerothermic grasslands, fallow fields, thermophilous scrub and oak forests, situated on river valley slopes, midfield escarpments, ravines or gorges, numerous in the area and developed mostly on the rocks of the Upper Cretaceous period.

Ten species belonging to five families: Asteraceae, Fabaceae, Lamiaceae, Apiaceae and Rubiaceae, were recorded as hosts of Orobanche species. Those are: Artemisia campestris (O. arenaria), Centaurea scabiosa (O. elatior), Cirsium arvense $(O$. pallidiflora), Picris hieracioides $(O$. picridis), Medicago falcata, M. sativa (O. lutea), Salvia verticillata $(O$. alba), Peucedanum cervaria (O. alsatica), Galium mollugo and G. verum (O. caryophyllacea).

This work is the first study to report the results of current and special research into the distribution, habitat conditions and hosts of species belonging to the genus Orobanche covering considerable areas in Poland.

\section{ACKNOWLEDGEMENTS}

The authors thank Wiaczesław Michalczuk and Janusz Wójciak for their help during field studies and Prof. Adam Zając for helpful comments on the manuscript.

This work was supported by the Ministry of Science and Higher Education (grant no. NN303357733(2007-2009) and NN303551939 (2010-2011).

\section{LITERATURE CITED}

BRÓŻ E., NOBIS M., PIWOWARCZYK R. 2001. Nowe stanowiska Orobanche picridis w Polsce. Chroń. Przyr. Ojcz. 57(5): 101-104. (in Polish)

CHATER A.O., WEBB D.A. 1972. Orobanche L. In: T.G. Tutin, V.H. Heywood, N.A. Burges, D.M. Moore, D.H. Valentine, S.M. Walters, D.A. Webb, Flora Europaea 3, Diapensiaceae to Myoporaceae, 286-293. Cambridge University Press, Cambridge.

FIJAŁKOWSKI D. 1964. Zbiorowiska kserotermiczne okolic Izbicy na Wyżynie Lubelskiej. - Xerothermic Communities in the Environs of Izbica in the Lublin Upland. Ann. UMCS Sect. C 19(14): 239-259.

FIJAŁKOWSKI D. 1991. Zespoły roślinne Lubelszczyzny. Lublin: Wydaw. UMCS.

FIJAŁKOWSKI D. 1994. Flora roślin naczyniowych Lubelszczyzny. T. 1. Lubelskie Towarzystwo Naukowe. Lublin.
FIJAŁKOWSKI D. 1995. Flora roślin naczyniowych Lubelszczyzny. Atlas. T. 2. Lubelskie Towarzystwo Naukowe. Lublin.

HALAMSKI A.T. 2005. Orobanche lucorum zawleczona do Ogrodu Botanicznego UW. - Orobanche lucorum introduced in the Botanical Garden of Warsaw University. Biuletyn Ogr. Bot. 14: 115-117. (in Polish with English summary)

KASZEWSKI B.M. 2008. Warunki klimatyczne Lubelszczyzny. Wyd. UMCS, Lublin.

KAŹMIERCZAKOWA R., ZARZYCKI K. (eds). 2001. Polska Czerwona Księga Roślin. - Polish Red Data Book of Plants. Polska Akademia Nauk, Instytut Botaniki im. W. Szafera, Instytut Ochrony Przyrody, Kraków, Polish Academy of Sciences, W. Szafer Institute of Botany \& Institute of Nature Conservations, Kraków. (in Polish with English summary)

KONDRACKI J. 2001. Geografia regionalna Polski. Wydawnictwo Naukowe PWN, Warszawa.

KREUTZ C.A.J. 1995. Orobanche: the European broomrape species. I. Central and northern Europe. Maastricht: Stichting Natuurpublicaties Limburg.

KUCHARCZYK M. 2001. Distribution Atlas of Vascular Plants in the Middle Vistula River Valley. Maria Curie-Skłodowska University Press, Lublin.

MATUSZKIEWICZ W. 2006. Przewodnik do oznaczania zbiorowisk roślinnych Polski. Vademecum Geobotanicum. PWN Warszawa.

MĄDALSKI J. 1967. Orobanchaceae. In: Pawłowski B., Flora Polska. Tom XI, 25-53; Warszawa, Kraków.

MIREK Z., PIĘKOŚ-MIREK H., ZAJĄC A., ZAJĄC M. 2002. Flowering plants and pteridophytes of Poland - a checklist. In: Z. Mirek (ed.), Biodiversity of Poland 1. Instytut Botaniki im. W. Szafera, Polska Akademia Nauk, Kraków, 1: 3-442.

PACZOSKI J. 1888. Spis roślin zebranych w 1887 w powiecie hrubieszowskim guberni Lubelskiej. Pam. Fizjogr. 8: 203-213.

PIWOWARCZYK R. 2006. Róża francuska Rosa gallica L. na Przedgórzu Iłżeckim (Wyżyna Małopolska). - Rosa gallica L. in the Iłża Foreland (Małopolska Upland). Chroń. Przyr. Ojcz. 62: 55-60. (in Polish with English summary)

PIWOWARCZYK R. 2010a. Distribution and phytocoenotic preferences of Orobanche mayeri (Suess. et Ronniger) Bertsch - a new species in Poland. In: W. Kurek, K. Marciszewska, A. Szczepkowski (eds), Proceedings of the 55th Meeting of the Polish Botanical Society "Planta in vivo, in vitro et in silico", September 6-12, 2010, Warsaw, Poland. Acta Soc. Bot. Pol. 79, Supplement 1: 52-53.

PIWOWARCZYK R. 2010b. Rośliny naczyniowe wschodniej części Przedgórza Iłżeckiego (Wyżyna Małopolska). Vascular plants of the eastern part of the Ilża Foreland (Małopolska Upland). Prace Bot. 43: 1-344.

PIWOWARCZYK R. 2011. Orobanche mayeri (Suess. \& Ronniger) Bertsch \& F. Bertsch - a species new to Poland. Acta Soc. Bot. Pol. 80. (in print)

PIWOWARCZYK R., CHMIELEWSKI P., GIERCZYK B., PIWOWARSKI B., STACHYRA P. 2010. Orobanche pallidiflora Wimm. \& Grab. in Poland: distribution, habitat and host preferences. Acta Soc. Bot. Pol. 79(3): 197-205.

PIWOWARCZYK R., PRZEMYSKI A. 2010. Distribution and habitat preferences declining species of Orobanche arenaria (Orobanchaceae) at the northern limit of its geographical range. Acta Soc. Bot. Pol. 79(1): 43-50.

PUSCH J., GÜNTHER K.-F. 2009. Orobanchaceae (Sommerwurzgewächse). In: G. Hegi (ed.), Illustrierte Flora von Mitteleuropa Bd. 6/1A, Lieferung 1. Weissdorn-Verlag, Jena.

SZCZĘŚNIAK E. 2003. Rzadkie i zagrożone gatunki ciepłolubnych muraw na Dolnym Śląsku. In: Z. Kącki (ed.), Zagrożone gatunki flory naczyniowej Dolnego Śląska. Endangered vascular plants of Lower Silesia. pp.: 85-107. Instytut Biologii Roślin, Uniwersytet Wrocławski, Polskie Towarzystwo Przyjaciół Przyrody "Pro Natura”, Wrocław. 
URBAN D., ŁUCZYCKA-POPIEL A. 1995. Walory florystyczne dorzecza Ciemięgi na Wyżynie Lubelskiej. Chrońmy Przyr. Ojcz. 51(2): 89-93.

ZAJĄC A. 1978. Założenia metodyczne "Atlasu rozmieszczenia roślin naczyniowych w Polsce”. Wiad. Bot. 22(3): 145-155. (in Polish)

ZAJĄC A., ZAJĄC M. (eds). 2001. Atlas rozmieszczenia roślin naczyniowych w Polsce. - Distribution Atlas of Vascular Plants in Poland. Nakładem Pracowni Chorologii Komputerowej Instytutu Botaniki Uniwersytetu Jagiellońskiego, Kraków.

ZARZYCKI K. 2001. Orobanche picridis F. W. Schultz - Zaraza goryczelowa. In: R. Kaźmierczakowa, K. Zarzycki (eds),
Polska Czerwona Księga Roslin, Polish Red Data Book of Plants, pp. 342-343. Polska Akademia Nauk, Instytut Botaniki im. W. Szafera, Instytut Ochrony Przyrody, Kraków, Polish Academy of Sciences, W. Szafer Institute of Botany \& Institute of Nature Conservations, Kraków. (in Polish with English summary)

ZARZYCKI K., SZELĄG Z. 2006. Red list of the vascular plants in Poland. In: Z. Mirek, K. Zarzycki, W. Wojewoda, Z. Szeląg (eds), Red list of plants and fungi in Poland. pp.: 9-20. W. Szafer Institute of Botany, Polish Academy of Sciences, Kraków. 